\title{
How and why do subcontractors experience different safety on high-risk work sites?
}

\author{
${ }^{\text {a }}$ Safety Science Innovation Laboratory, School of Humanities, Languages and Social \\ Sciences, Griffith University, Nathan 4111, QLD Australia.

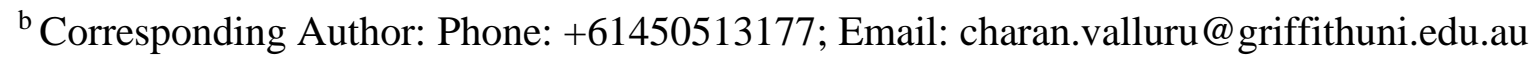
8

\begin{abstract}
:
In high-risk industries such as construction, mining and energy, subcontractors play an increasingly significant role. A typical arrangement is for the site owner to hire a principal contractor who in turn hires multiple subcontractors. This means that multiple subcontractors from multiple companies can be working on the same site at the same time.

There is evidence that the use of subcontractors is not only increasing, but that the accident rates for subcontractor employees are higher than those of operator/site owner employees Existing research on subcontractors, which focuses on the role of the prime contractor in selecting and managing subcontractors, fails to explain why subcontractors continue to experience higher rates of serious injury even where subcontractor management systems are in place.
\end{abstract}

The purpose of this paper is to understand how and why employees of subcontractors' experience safety differently from employees of principal contractors. The paper does so by extensively reviewing the applicable literature and reporting on a cross-industry focus group study.

Keywords: Subcontractors; Working conditions; safety management; qualitative methods

\section{Acknowledgement:}

Following a workplace incident that occurred in 2011, Thiess entered into an Enforceable Undertaking (EU) with the regulator from the Office of Fair and Safe Work Queensland on 24 July 2014.

As part of EU and as a safety benefit for industry, Thiess committed to providing a 3-year scholarship to a Griffith University OHSS student to support research into the relationship between principal contractors and subcontractors in the construction industry.

The authors gratefully acknowledge the contribution of Simon Albery from Thiess in organizing the workshop and reviewing drafts of this paper. 
Safety of subcontractor employees in high-risk industries has become a topic of significant academic and industry interest (Chernoff, 1980; Hinze \& Gambatese, 2003; Lamare, Lamm, McDonnell, \& White, 2015; Mayhew, Quintan, \& Ferris, 1997). There is evidence suggesting both that the use of subcontractors is increasing (Quinlan, 2014) and that the accident rates associated with subcontractor employees are higher than those of operator employees (Muzaffar, Cummings, Hobbs, Allison, \& Kreiss, 2013). Existing research on subcontractors, which focuses on the role of the prime contractor in selecting and managing subcontractors, fails to explain why subcontractors continue to experience higher rates of serious injury even where subcontractor management systems are in place. In this paper, we seek to understand how and why employees of subcontractors' experience safety differently from employees of principal contractors. The paper does so by extensively reviewing the applicable literature and reporting on a cross-industry focus group study. It is structured as follows. In Section 2 of the paper, we provide a brief literature review to explain what we know about subcontractor safety so far. It is established in the literature (see above) that subcontractors are at higher risk. We have reason to believe that this is because subcontractors perform more dangerous work, and have weaker systematic safety protection while doing so. This characterises the problem, but does not explain it, so in Section 3 (method) and Section 4 (results) we report on a focus group study to explore the paper's core question: How and why are subcontractor employees treated differently on high risk work sites and what are the possible links to their safety?

\subsection{A brief primer on subcontracting}

Most mining and construction sites are operated by a "general contractor", also variously called a 'prime' (Ivensky, 2008) or 'principal' contractor (H. C. Lingard, Cooke, \& Blismas, 2010). These contractors are generally responsible for the entire project and are only answerable to the site owner. Workers on the site are either directly employed by the general contractor, or via some form of non-employment contract. Two key examples ( $\mathrm{Ng}$, Tang, \& Palaneeswaran, 2009) are specialist subcontractors, who are employed to perform a specific task onsite, and labour hire contractors hired to fill temporary shortages of labour. Specialist subcontractors are typically permanent employees of smaller businesses who have been contracted by the general contractor. Labour hire subcontractors' employees generally work alongside the employees of the general contractor but are paid by the subcontractor (Crush, Ulicki, Tseane, \& van Veuren, 2001) for the number of hours worked. In construction, subcontractors often perform most of the work on a project, sometimes nearing $90 \%$ of the total project value (Mohan M. Kumaraswamy \& Jason D. Matthews, 2000). Subcontracting has been seen as a means to make projects more cost effective and to transfer the risks from the ownership company onto other parties (Chen \& Jin, 2015; Hsieh, 1997).

Subcontract employees fall under the broader category of "precarious" or "contingent" employment (Min et al., 2013; Quinlan \& Bohle, 2004; Rousseau \& Libuser, 1997). While there is no universal definition for precarious work, it is generally held to include four dimensions (Rodgers \& Rodgers, 1989):

- Temporal - uncertain duration and continuation of work;

- Economic - lower pay and less regularity in pay;

- Social - less structural protection against poor working conditions and unfair or unsafe practices; and 
- Organisational - lower individual or collective autonomy and bargaining power.

All four of these dimensions apply to some extent to subcontractor work and reflect the differences between subcontractor employees' and principal employees' working conditions. Other authors have used terms such as 'flexible' (Leach, 1993; Thébaud-Mony, 2011) and 'outside' workers (Thébaud-Mony, 2011) to describe the nature of work performed by subcontractors. These labels provide hints as to the nature of the subcontract employee safety problem. Whilst the problem starts with contract terms and employment status, it manifests as a broader problem of work relationships.

Subcontractors are visitors and outsiders. They do not 'really belong,' and therefore they are not cared for in the same way as permanent employees. Barley \& Kunda, (2006) in their study of contract employees suggest that this feeling of being treated as 'second-class citizens' did not change. No matter how much these workers tried to feel included, there were always ways in which they were made to feel otherwise with some even reporting an increase in stress. For example, an organization that has been awarded for safety excellence also had inferior contract conditions and provided lower standard living quarters and even had preferential treatment for its own employees when compared to that of its contractors' (Collinson, 1999). A study of highly specialist contractors shows that they position themselves as 'outsiders' (Bryant \& McKeown, 2016), since they are often made to feel not part of the group. Current reporting channels such as lost-time injuries (LTIs) aimed at improving safety are often thought to be counterproductive. Subcontractor employees could get penalised for LTIs hurting their chances of future employment while the principal contractor employees with possible links are left ignored (Dekker, 2014).

\section{Literature Review}

\subsection{Subcontractors are at a higher risk}

Despite evidence that subcontractor employees are less likely to report injuries (Kenny \& Bezuidenhout, 1999), they still are involved in a higher rate of reported serious injuries and fatalities. Studies show that subcontract employees face greater risk when it comes to work related diseases and absenteeism when compared to permanent employees (Min et al., 2013) and also have higher proportion of fatal injuries (Muzaffar et al., 2013).

Lamare et al., (2015), cite the Pike River Coal Mine disaster of 2005 as a case study to help understand how pressing the situation of on-site contractor safety is. The incident, which involved multiple methane gas explosions, resulting in the loss of 29 lives, of which 13 were contractor employees. The site management was found lacking proper records of the locations of contractors on site; hiring of contractors who had no previous experience of working on a mine site, and missing a proper Safety Management System for contractor employees (Macfie, 2013).

The use of subcontracting has gone up steadily over the past few decades. As of August, 2015 there are over one million independent contractors in Australia (Australian Bureau of Statistics, 2016). In the Australian construction industry, subcontracting alone was responsible for 93.6 billion dollars during the 2011-2012 financial year making up 40.1\% of the total income in this industry (Australian Bureau of Statistics, 2013). 
The industries that employ most subcontractors have consistently recorded some of the highest numbers in terms of fatalities and injuries. In Australia between 2007 and 2012, 36 mining workers have lost their lives in the performance of job duties (Safe Work Australia, 2013) while the construction industry recorded 49 fatal incidents between 2012 and 2013 (Safe Work Australia, 2015). As per the latest available statistics on Safe Work Australia, there has been a decline in the number of incidents resulting in fatalities and serious injuries in both these industries. However, the incidence rates remain way above the national rate. For instance, the mining industry has recorded an incidence rate of 3.84 per 100000 workers, $70 \%$ higher than the national rate for all industries (Safe Work Australia, 2009).

A report of the Queensland government's Department of Natural Resources and Mines documents that out of the 8 mining industry fatalities that occurred in Australia between August 2013 and February 2014, 5 were contractors (Department of Natural Resources and Mines, 2014). The year continued in two more contractor deaths.

Outside Australia, there have been studies that provide similar findings about the risk that subcontractors face. In the US construction industry, one study related an increase in subcontracting as directly linked to the increase in injury rates onsite (Azari-Rad, 2015), while another investigation noted that $59 \%$ of deaths caused by trench collapses involved subcontractors (Suruda, Whitaker, Bloswick, Philips, \& Sesek, 2002). An investigation of shipyard related fatalities in Turkey documented $25 \%$ of fatal workplace incidents were related to subcontractors (Barlas, 2012).

\subsection{Subcontractors are less protected by institutional safety mechanisms}

Quinlan \& Bohle (2004), categorise factors that help in understanding poorer safety outcomes for precariously employed workers in to three categories: pressures, disorganization and regulatory failure (Underhill \& Quinlan, 2011).

\subsubsection{Subcontract employees are subject to different "pressures"}

"Pressures" refer to the economic and reward conditions that affect the safety of contractor employees. There are two directions in which this can further be classified. First is from the contracting company's perspective of increase in competition for work and the second is in the form of job and income insecurity from the contractor employee's point of view.

There are various means used to identify potential subcontractors for a project (Abbasianjahromi, Rajaie, Shakeri, \& Kazemi, 2016). Sometimes, before the actual bidding process begins, clients and principal contractors perform contractor assessments to determine whom to consider for the bidding process. Contractor qualification and contractor certification processes are matched for job fit. Then, the principal or the owner of the project calls for bids for various contracting works available on site and the subcontractor company quoting the lowest bid is generally awarded the contract (Hinze \& Tracey, 1994).

While it is true that multiple factors are being considered in awarding a contract, pricing continues to remain on top of the list (Hartmann, Ling, \& Tan, 2009). This trend, in addition, to increasing competition and lowering costs for the ownership company, results in more subcontractors limiting cost by pushing safety of their employees down the list of priorities 
1 (Lamare et al., 2015; Min et al., 2013). Researchers propose taking the safety track record of 2 the subcontractors into consideration when choosing a subcontractor company should be a 3 greater priority (Huang \& Hinze, 2006; Ng, Cheng, \& Skitmore, 2005; Roughton, 1995). While uncertain whether these genuinely reward safety. Only a few cases where there has been an improvement after implementing this strategy have been reported.

Subcontractors face delayed payments. In a survey issued to owners, contractors and subcontractors, $89 \%$ of the subcontractors responded that their payments were delayed by more than 45 days (Arditi \& Chotibhongs, 2005). Sometimes clauses such as pay-when-paid and pay-if-paid are included in the contract to subcontractors in order to delay payments to the subcontractor (Kirksey, 1992; Uher, 1991).

From the contractor employees' viewpoint, reporting an injury is not looked upon too favourably in terms of continued employment (Kenny \& Bezuidenhout, 1999; Quinlan \& Bohle, 2004). There are often instances where injuries go unreported or underreported. For example, on offshore platforms on North Sea oil, subcontractors were often seen to be reluctant in reporting incidents and injuries as they were worried these would be taken as Key Performance Indicators (KPIs) and potentially limit their access to work (Collinson, 1999). In the South African mines it is not unusual to learn that some injuries go unreported and contract employees continue to work with injuries in some cases (Crush et al., 2001). Subcontractor employees are also known to work longer work hours and hold multiple jobs which may increase their safety risk in order to maintain financial stability as their output determines their wages (Lamare et al., 2015).

\subsubsection{Subcontractors are less protected by safety management systems (SMS)}

Management's commitment to safety is known to be the biggest driver when it comes to influencing safety on large sites in high-risk industries (Ali, Abdullah, \& Subramaniam, 2009; Butz. R.M., Dietz, J., \& Konovsky, M.A., 2001; Sawacha, Naoum, \& Fong, 1999; Zohar, 1980; Zohar \& Luria, 2003). The usual processes management has in place include an adequate SMS, proper and regularly scheduled training, and appropriate Personal Protective Equipment (PPE). Subcontractor employees generally tend to trust the management comprising of principal's staff when it comes to their safety on site in these industries (Sætren \& Laumann, 2015). However, when it comes to the contractor employees, there has existed confusion as to the responsibility for their safety (Johnstone, Mayhew, \& Quinlan, 2000) especially with choosing which SMS to adhere to. Minor subcontractors find it difficult to maintain their own safety systems for their workers and hence depend on the principal's SMS. While the SMS of the larger subcontracting companies may be equal or superior to those of the principal contractor, complexity of having to manage multiple systems across many geographical locations can create issues (Bahn, 2012). However, anecdotal evidence suggests that they would almost always need to implement the principal's SMS. Additional problems arise from a lack of experience of the safety team of the contractor (Huang \& Hinze, 2006) and from the failure of proper communication between the teams from various contractors who may all be working on the same site (M. Loosemore \& Andonakis, 2007; Simon \& Piquard, 1991). On large sites, the contractor is usually at the end of line in a project (H. Lingard \& Holmes, 2001). As Quinlan $\&$ Bohle, (2004) point out, the contractor employees often face higher economic pressures and disorganization at the workplace which could lead to a lack of proper communication and coordination between teams resulting in a negative impact on safety. 
2 A workplace induction process typically involves providing the new employees with all aspects 3 of the job including technical and safety related training. Lack of training provided by the site 4 owner or principal (Hinze \& Gambatese, 2003; Rebitzer, 1995) has been shown to have a mining are small to medium companies with most of them just employing under 20 people (Gunningham, 2008; H. Lingard \& Holmes, 2001). Some of these small contractors are known to cite high implementation costs, language and education hurdles and a fear of change (M. Loosemore \& Andonakis, 2007) as reasons for not implementing proper Occupational Health and Safety (OHS) standards and education. There are a number of occasions when site specific training is left to the subcontractors by the site management (Gunningham, 2008).

Several researchers have shown that factors otherwise working in favour of the safety for regular employees tend to not work so well when it comes to subcontractors. Subcontractors are directly impacted by lack of proper tools, crib facilities and most importantly incorrect or absent PPE (Goldenhar, Moran, \& Colligan, 2001; H. Lingard \& Holmes, 2001), Further issues arise for contracted workers in the unavailability of access to proper health facilities (Papadopoulos, Georgiadou, Papazoglou, \& Michaliou, 2010; Uher \& Ritchie, 1998), irregular working hours, extended workdays and poor work conditions (Hinze \& Gambatese, 2003), alcohol and drug use by contractor employees which may be unmonitored and lack identification and treatment management on principal sites (Goldenhar et al., 2001), minimal requirements of principal's supervision of contractor employees while on-site ( $\mathrm{Ng}$ et al., 2005; Rebitzer, 1995) and the presence of employees from non-English speaking backgrounds (Trajkovski \& Loosemore, 2006).

\subsubsection{Subcontract employees are less protected by regulatory action}

This final classification deals with factors due to which regulatory functions (OHS and employment) could be influenced by employing subcontractors. This holds to be even truer in terms of labour hire subcontractors even though most government regulations do not differentiate between regular employees and contractor employees. Two hundred regulatory officials surveyed revealed that the very nature of temporary employment makes it difficult to enforce OHS regulations (Johnstone \& Quinlan, 2006). Additionally, being part of a union puts regular employees at far less risk than contractor employees who do not have adequate union access (Gillen, Baltz, Gassel, Kirsch, \& Vaccaro, 2002). This could be due to the growing number of casual employees being employed by subcontractors (Rousseau \& Libuser, 1997). In some conditions where subcontractors do try to uphold compliance with the regulations necessary to maintain proper OHS, not all are successful in doing so. This could be a result of trying to finish the project in the given time or out of ignorance or in some cases might not be aware of the said regulation (Hislop, 1999).

\subsection{Subcontractors undertake riskier work}

One of the less discussed concerns of subcontractor related work is that it is riskier in nature when compared to tasks of regular employees.

A mining example from the African gold mines documents that subcontractor employees (labour-hire) are generally assigned to work in the most dangerous parts of the mines where regular miners (and their union representatives) have declined to work. This is in addition to 
the fact that these temporary employees are often working longer hours as the mine management does not monitor their shifts to the same extent as full employees (Crush et al., 2001).

A review of the Swedish mining sector's occupational injury data notes that there is a shortage of data related to subcontractor workers' safety incidents and that the results indicate that their injuries are of higher rate and severity. The review also suggests that these employees also seem to be performing dissimilar tasks and working under different conditions than permanent employees when incidents occur (Blank, Andersson, Lindén, \& Nilsson, 1995).

The nuclear industry, known to be at the forefront of industrial safety owing to its high-risk nature, also has a few examples when it comes to the distribution of higher risk to subcontractor employees. A Japanese nuclear industry subcontractor employees' study reported that these employees were doing the work that poses the highest risk in the most dangerous sections of the plant and were being exposed to higher radiation (Moore, 1997). A recent review of the issue at the Fukushima nuclear plant, documented the number of subcontractor employees hired to complete the cleaning work were being exposed to high radiation is more than eighteen times than that of the regular employees (Jobin, 2011). Specialist subcontractors are often employed in the most hazardous phase of nuclear decommissioning related tasks which are important and take the longest to complete (Owen, Healey, \& Benn, 2013). A study which dealt with subcontractor employees working in the French nuclear industry came up with similar revelations. These employees were working in areas of higher risk facing confined time schedules and higher work-pace and demands (Thébaud-Mony, 2011).

Responses collected from contingent workers from the USA in interviews conducted by Padavic, (2005), discuss other factors that may impact safety. Subcontractors are not considered to be part of a team, must plead to get a day off, face non-payment in certain cases, and are assigned more difficult and dangerous jobs to perform.

A study by Roquelaure et al., (2012), suggests that while there were no significant differences between the injuries reported by temporary workers when compared to permanent employees working in France, there was evidence to suggest that temporary employees were facing more work time constraints and more repetitive work that put them at a higher perceived risk score of musculoskeletal injuries. Another study based on a sample from the Korean Working Conditions Study suggests that subcontracted employees usually face more hazardous working conditions resulting in higher rate of absenteeism and involving larger risk of occupational disease (Min et al., 2013).

\section{Method}

We organised a one-day workshop structured as a series of focus group exercises with twentyone participants. The participants included operational, contractor and safety staff from construction, mining, and related services companies, as well as representatives from Department of Justice, and Workplace Health and Safety Queensland. The participant companies operate as both principal contractors and subcontractors depending on the project.

The room was split into three discussion tables and participants were allocated randomly to each table. Each table had a facilitator to help participants understand what was expected of them. The tables had a white sheet in the centre, covering five categories drawn from the axial 
1 coding paradigm model used by Strauss and Corbin (Strauss \& Corbin, 1998). Axial coding

2 was used to develop themes associated with a particular phenomenon.

3 The five categories were:

- Cause - what leads to the phenomenon?

- Properties - what can be measured about the phenomenon?

- Conditions - what causes the phenomenon to vary?

- Consequences - what are the results of the phenomenon?

- Strategies - how can the phenomenon be addressed?

Every group was asked to discuss two phenomena in turn. The first phenomenon presented to them was: "When contractors on site are not full team members". The second phenomenon was: "When commercial arrangements with contractors inhibit safety". These phenomena were selected using an online survey of the participants prior to the workshop. The survey asked participants to rate the relative importance of various problems with contractor safety, to ensure that the table sessions were relevant to the needs and interests of participants.

For each phenomenon, participants were asked to write and place sticky notes with as much or as little detail as they desired. They then discussed the notes and placed further notes to reflect the discussion. The collected notes formed the basis of the post-workshop analysis.

The second half of the workshop consisted of a facilitated change exercise, in which participants were asked to consider what they would like to:

- do more of;

- do less of;

- stop doing; and

- start doing

Participants were encouraged to make a mental commitment to two changes, and then imagine a future in which they failed to live up to this commitment. The purpose of this exercise was to help participants visualize the barriers for improving subcontractor safety. Participants then formed into teams to coordinate further action. It is the understanding of the researchers that this final exercise led to ongoing co-ordinated action between participants for the creation of common resources for contractor education. This is a positive outcome of the workshop, but further tracking of such activities is beyond the current scope of the project.

\section{Results}

The topics discussed by the participants fall naturally into three clear categories:

1. Fixed conditions - things that influence contractor safety, but are not readily alterable without extensive shifts in the contracting and industry landscape

2. On-site conditions - issues that are somewhat influenced by the fixed conditions, but can also be addressed by direct action. 
13 . Outcomes - problems with contractor safety that arise from fixed or on-site conditions, but which cannot themselves be directly addressed except to mitigate harmful effects once they have occurred.

\subsection{Fixed conditions}

\subsubsection{Project conditions}

Both market conditions and project lifecycles result in varying time and cost pressure on contractor relationships. Participants referred to both "boom" and "bust" conditions as problematic. Boom conditions result in a high tempo of work, with an expanding workforce combined with a focus on production to meet demand and capitalize on high prices. Bust conditions involve a contracting workforce, with a focus on cost saving and careful allocation of available resources. Neither condition is amenable to spending time and effort on developing contractor skills or managing safety beyond addressing immediately-present hazards.

\subsubsection{Workforce conditions}

The capability of subcontractor employees to safely perform their designated tasks was a recurrent theme in the workshop. Subcontractor training and skill level - including at the management and safety team level as well as the front-line workforce - is highly variable. While almost all principals provided safety inductions and safety training to their subcontractors, many participants felt they were unhelpful. Phrases such as stop 'death by PPT (PowerPoint) inductions' and start 'interactive inductions' suggested the ineffectiveness of these programs. Subcontractor selection processes are not necessarily incentivized to select skilled contractors, particularly where (at least in the short term) the risk for poor performance appears to be borne by the contractor organisation rather than the principal. Some participants suggested that they would like to see less of 'collection of lag indicators as selection criteria' and 'our accreditation depends on having a contractor assessment system' mindset when it comes to subcontractor selection. Language and literacy were also raised as workforce capability issues.

\subsubsection{Industry regulations and collective organisation}

Unionization has shown a positive effect on site safety in many industries. A comparison of union and non-union construction sites revealed that sites with unions were more scrutinized during inspections by respective authorities when compared to non-unionized locations (Weil, 1992). In the American mining industry, unionization provided a significant decline in injuries and fatalities (Morantz, 2013). The role of unions as an influence on contractor relations was mentioned by a number of participants - usually but not entirely unions were referred to as a negative influence. Another factor that received attention during the discussion was the role of regulators. While regulations are intended to help promote a better functioning and safer work environment, several participants indicated that company systems to meet legislative requirements were overly prescriptive and interfered with safety.

\subsection{On site conditions}




\subsubsection{Leadership}

Leadership is an important dimension of safety climate, which in turn is believed to influence safety (Bryden R., 2002; Zohar, 1980). 'Leadership', and 'direction' were mentioned frequently in the workshop. Participants considered that principal contractors had a responsibility to provide leadership that included subcontractors, and that this responsibility was not being discharged. 'Lack of senior management commitment to change', less of 'command and control leadership' and need more of 'senior management site walks and one on one interaction with project team workers' were statements made by them that enforced the importance of leadership. Leaders within principal contractors relate to their own staff in different ways than they do with subcontractors. Often, they do not have a direct relationship with contractor staff, 'leading' through layers of management in the contractor organisation.

\subsubsection{Trust}

Trust plays an important role in helping multiple teams work together on a site. Evidence exists to suggest the increasing role of trust as a factor in influencing the safety culture of a workplace (Conchie, Donald, \& Taylor, 2006). From the point of view of the participants, trust has an even larger role to play to help enhance the safety condition of sites. With regards to onsite relation between the principal and the subcontractors, one participant said, 'adversarial power plays by dominant PCs (principal contractors)' needs to be stopped. Some have mentioned phrases such as 'uncertainty', 'disengaged' and 'communication amongst team may not be consistent' as effects of lack of trust. In fact, many participants wanted to see more of 'contractor coordinated pre-starts', 'building relationship with subbies teams', and 'engaging in meaningful conversations with/between contractors' and less of 'immediate dismissal of contractors for safety breaches'.

\subsubsection{Commercial arrangements}

Commercial arrangements affect subcontractors in more than one way. Many participants mentioned commercial arrangements, particularly with respect to contractor selection. 'Cost is main criteria', 'lowest bidder', 'all stakeholders are in business to make a PROFIT' and 'contractor selection - lowest cost'. Others have mentioned issues with regards to contractor insurance and issues with regards to 'who pays for site safety initiatives/time', client insurance versus contractor insurance base', and 'who is bearing the risk-insurance'. Various phrases suggesting contractual obligations as a problem have also been mentioned. For example, 'commercial contract restricts sharing of information', 'cost pressures example contract renewals', and 'contract price too low to pay for safety' were seen. Some participants even felt that 'subcontractors are engaged in a rush with no time for pre-engagement assessments'.

\subsubsection{Isolated teams:}

This was an important part of the discussion amongst the participants. Various aspects of how subcontractors often acted as isolated teams were mentioned. There was a consensus that this negatively impacted effective communication between the principal and the contractor staff. Issues such as 'different SMS on site', 'disjointed', 'have their own site sheds', 'self-selection into teams' and 'lack of common goal/strategic direction' were mentioned. Some participants also mentioned probable results of this nature of the subcontractors as 'non-receptive to communication', 'infrequent interaction', and 'different levels of communication'. This 
becomes an important aspect to further be investigated, as it is important for effective communication to exist so that teams can work towards common goals such as safety.

\subsubsection{Goals/Expectations}

There is a paradox in that safety is frequently both an explicit goal and expectation, and implicitly a low-priority consideration. This is encapsulated in the sticky note 'Safety is an expectation, but not something clients care about'. Participants frequently mentioned inconsistency in standard, goals, values, expectations, and agendas related to safety. There were several views on what the participants wanted to see when it came to goals/expectations. While one wrote that he/she would like to see less of 'adding more paperwork to documents', others have written 'developing complicated procedures for tasks', 'subbie selection based mostly on price', 'make new rule every time something goes wrong' and 'collecting irrelevant data' as things they would like to see happen less.

\subsection{Outcomes}

17

\subsubsection{Project risk}

This refers to the shift of risk from the principal to the subcontractor. Participants have mentioned phrases such as 'schedule doesn't allow for risks to be addressed early or designed out' and 'shifting risk base from client'. While some have directly mentioned that they would like to see less of 'hiding behind contractor', others have mentioned issues such as 'blocking communication channels', 'project outcomes not achieved', 'schedule clashes', 'inefficiency', 'poor quality' and 'adverse relationship' as outcomes of this risk shift.

\subsubsection{Site safety}

Participants have pointed to issues such as 'risk to others', 'increased IR issues', 'site conditions are not understood', and 'principal loses visibility of risk in work done on the ground' as site safety issues that would arise out of the contractor process.

\subsubsection{Mental wellbeing/Happiness}

High risk industries such as construction are related to poorer mental wellbeing and greater stress (Martin Loosemore \& Waters, 2004). When it comes to subcontractors, temporary work arrangements seem to already add to the existing stress levels. There is evidence in the literature suggesting temporary employment is linked to indicators of poor health (Lewchuk, Clarke, \& Wolff, 2008). A study conducted in the construction industry revealed that contractor employees working on the site showed signs of poorer mental health and greater work stress when compared to others (Love, Edwards, \& Irani, 2010). Some participants felt that wellbeing of contractor employees could be affected because of the contracting process in its present condition. Phrases such as 'health issues e.g. Mental', 'not feel part of the team (not valued)' were mentioned on occasions during the discussion. Some organizations suggested that support groups and psychological help was available to employees of only principal or larger contractors. 


\section{Discussion}

Our work contributes to the body of knowledge on subcontractor safety by extending and refining the link between precarious work status and poor safety outcomes. The focus groups suggested several links between contracting arrangements and ways in which the subcontractor employee experience of safety management can be very different from the principal employee experience. This goes some way to explaining why extending the responsibilities of site owners and operators to cover subcontractors is insufficient to ensure equal treatment, even where safety policies are procedures appear to be written and applied uniformly.

An example supplied by one of the workshop participants illustrates this finding. On a large mine site, there were several work groups containing both principal contractors and labour hire subcontractors. These groups were subject to the same roster conditions, and the same safety management system. Each group operated on a roster schedule, $\mathrm{X}$ days at work followed by $\mathrm{X}$ days on break $(\mathrm{X}-\mathrm{X})$. Everyone in a group worked regularly together.

Due to market conditions, the company desired to reduce labour hire subcontractor attrition. They changed the subcontractor roster to one viewed as more attractive (Y-Y, Y > X). Under the site fatigue management rules, however, a roster of $Y-Y$ required a lower number of daily hours to be worked.

The principal contractor employees were kept on the original $\mathrm{X}-\mathrm{X}$ roster schedule for two reasons:

1. The existing contractual agreements could not be changed quickly due to an Enterprise Bargaining Agreement (EBA).

2. The $X-X$ roster allowed the principal contractors to work longer daily hours increasing productivity.

This resulted in the $\mathrm{X}-\mathrm{X}$ and $\mathrm{Y}-\mathrm{Y}$ rosters being staggered, both in the start and finish times each day, and the start and finish days each month.

The outcomes of this change resulted in segregation of the principal contractor and labour hire subcontractor employees. The existence of 'principal contractor' teams and 'labour hire' teams resulted in the different groups being assigned different tasks and equipment. The different rosters meant that they attended different meetings, began, and ended the day at different times, and received different training.

Top down interventions do not fix emergent problems in complex socio-technical systems. Our study has shown that subcontractors have different experiences of safety at work due to interactions between fixed conditions (project conditions, workforce conditions and industry regulations and collective organization) on site conditions (leadership, trust, commercial arrangements, isolated teams and goals and expectations), and outcomes (project risk, site safety and mental wellbeing/happiness).

Attempts to improve safety for subcontractor employees by creating uniform regulations and management systems to cover all workers will not remedy the fact that organisations deliberately enter subcontracting arrangements precisely because they offer productivity 
1 advantages. These benefits for the business translate into precarious work arrangements, which 2 in turn mean that subcontract employees have different experiences of work.

3

\section{More study is needed to understand how these differences translate into increased danger. The} increased risk experienced by subcontractors is partly explained as a transfer of existing risk, but this is unlikely to be the full picture. Are segregation and 'outsider' status themselves safety risks? If so, to what extent can safety practices be modified to better suit subcontractor employees as a specific at-risk population? 


\section{References:}

Abbasianjahromi, H., Rajaie, H., Shakeri, E., \& Kazemi, O. (2016). A new approach for subcontractor selection in the construction industry based on portfolio theory. Journal of Civil Engineering and Management, 22(3), 346-356. https://doi.org/10.3846/13923730.2014.897983

Ali, H., Abdullah, N. A. C., \& Subramaniam, C. (2009). Management practice in safety culture and its influence on workplace injury: An industrial study in Malaysia. Disaster Prevention and Management, 18(5), 470-477. https://doi.org/10.1108/09653560911003660

Arditi, D., \& Chotibhongs, R. (2005). Issues in Subcontracting Practice. Journal of Construction Engineering and Management, 131(8), 866-876. https://doi.org/10.1061/(ASCE)0733-9364(2005)131:8(866)

Australian Bureau of Statistics. (2013). Private Sector Construction Industry, Australia, 2011-12 (No. 8772.0). Canberra, Australia. Retrieved from http://abs.gov.au/AUSSTATS/abs@.nsf/Latestproducts/8772.0Main\%20Features2201 $1-12$ ?opendocument $\&$ tabname $=$ Summary $\&$ prodno $=8772.0 \&$ issue $=2011$ $12 \&$ num $=\&$ view $=$

Australian Bureau of Statistics. (2016). Characteristics of employment, Australia (No. 6333.0). Canberra, Australia. Retrieved from http://www.abs.gov.au/ausstats/abs@.nsf/Latestproducts/6333.0Main\%20Features4A ugust $\% 202015$ ?opendocument $\&$ tabname $=$ Summary \&prodno $=6333.0 \&$ issue $=$ August $\% 202015 \&$ num $=\&$ view $=$

Azari-Rad, H. (2015). Subcontracting and Injury Rates in Construction. Members-Only Library, O(0). Retrieved from http://50.87.169.168/OJS/ojs-2.4.41/index.php/LERAMR/article/view/1296

Bahn, S. (2012). Moving from contractor to owner operator: impact on safety culture - a case study. Employee Relations, 35(2), 157-172. https://doi.org/10.1108/01425451311287853

Barlas, B. (2012). Shipyard fatalities in Turkey. Safety Science, 50(5), 1247-1252. https://doi.org/10.1016/j.ssci.2011.12.037

Barley, S. R., \& Kunda, G. (2006). Contracting: A New Form of Professional Practice. Academy of Management Perspectives, 20(1), 45-66. https://doi.org/10.2307/4166218

Blank, V. L. G., Andersson, R., Lindén, A., \& Nilsson, B.-C. (1995). Hidden accident rates and patterns in the Swedish mining industry due to involvement of contractor workers. Safety Science, 21(1), 23-35. https://doi.org/10.1016/0925-7535(95)00004-6

Bryant, M., \& McKeown, T. (2016). Experts, outsiders or strangers? The self-positioning of highly skilled contractors. Journal of Management \&amp; Organization, 22(3), 388403. https://doi.org/10.1017/jmo.2015.41

Bryden R. (2002). Getting serious about safety: accountability and leadership - the forgotten elements. Presented at the Proceedings of Society of Petroleum Engineers Health, Safety, Environment conference, Kaula Lumpur. 
Butz. R.M., Dietz, J., \& Konovsky, M.A.,. (2001). Top management and immediate supervisors as distinct targets of trust. Presented at the 16th Annual Conference of the Society for Industrial and Organizational Psychology, San Diego, CA.

Chen, Q., \& Jin, R. (2015). A comparison of subgroup construction workers' perceptions of a safety program. Safety Science, 74, 15-26. https://doi.org/10.1016/j.ssci.2014.11.021

Chernoff, D. C. (1980). Independent Contractor Safety in the Mines: A Review and Analysis of Regulatory History with Proposals for Change Black Lung Symposium. West Virginia Law Review, 83, 945-976.

Collinson, D. L. (1999). 'Surviving the Rigs': Safety and Surveillance on North Sea Oil Installations. Organization Studies, 20(4), 579-600. https://doi.org/10.1177/0170840699204003

Conchie, S. M., Donald, I. J., \& Taylor, P. J. (2006). Trust: Missing Piece(s) in the Safety Puzzle. Risk Analysis, 26(5), 1097-1104. https://doi.org/10.1111/j.15396924.2006.00818.x

Crush, J., Ulicki, T., Tseane, T., \& van Veuren, E. J. (2001). Undermining Labour: The Rise of Sub-Contracting in South African Gold Mines. Journal of Southern African Studies, 27(1), 5-31.

Dekker, S. W. A. (2014). Deferring to expertise versus the prima donna syndrome: a manager's dilemma. Cognition, Technology \& Work, 16(4), 541-548. https://doi.org/10.1007/s10111-014-0284-0

Department of Natural Resources and Mines. (2014). 2013-14 shaping up to be a dangerous year for mining contractors. It doesn't have to be. - Department of Natural Resources and Mines (Commissioner safety alert No. 5). Retrieved from https://www.dnrm.qld.gov.au/mining/safety-and-health/alerts-bulletins-searchtool/alerts-bulletins-search/alerts-bulletins/mines-safety/2013-14-mining-contractorsnotice?SQ_DESIGN_NAME=print-fact-sheet

Gillen, M., Baltz, D., Gassel, M., Kirsch, L., \& Vaccaro, D. (2002). Perceived safety climate, job demands, and coworker support among union and nonunion injured construction workers. Journal of Safety Research, 33(1), 33-51. https://doi.org/10.1016/S00224375(02)00002-6

Goldenhar, L. M., Moran, S. K., \& Colligan, M. (2001). Health and safety training in a sample of open-shop construction companies. Journal of Safety Research, 32(2), 237252. https://doi.org/10.1016/S0022-4375(01)00045-7

Gunningham, N. (2008). Occupational Health and Safety, Worker Participation and the Mining Industry in a Changing World of Work. Economic and Industrial Democracy, 29(3), 336-361. https://doi.org/10.1177/0143831X08092460

Hartmann, A., Ling, F. Y. Y., \& Tan, J. S. H. (2009). Relative Importance of Subcontractor Selection Criteria: Evidence from Singapore. Journal of Construction Engineering and Management, 135(9), 826-832. https://doi.org/10.1061/(ASCE)07339364(2009)135:9(826)

Hinze, J., \& Gambatese, J. (2003). Factors That Influence Safety Performance of Specialty Contractors. Journal of Construction Engineering and Management, 129(2), 159-164. https://doi.org/10.1061/(ASCE)0733-9364(2003)129:2(159) 
Hinze, J., \& Tracey, A. (1994). The Contractor-Subcontractor Relationship: The Subcontractor's View. Journal of Construction Engineering and Management, 120(2), 274-287. https://doi.org/10.1061/(ASCE)0733-9364(1994)120:2(274)

Hislop, R. D. (1999). Construction Site Safety: A Guide for Managing Contractors. CRC Press.

Hsieh, T.-Y. (1997). The economic implications of subcontracting practice on building prefabrication. Automation in Construction, 6(3), 163-174. https://doi.org/10.1016/S0926-5805(97)00001-0

Huang, X., \& Hinze, J. (2006). Owner's Role in Construction Safety. Journal of Construction Engineering and Management, 132(2), 164-173. https://doi.org/10.1061/(ASCE)0733-9364(2006)132:2(164)

Ivensky, V. (2008). Safety Risk Management of Subcontractors: What is a standard of care? Professional Safety, 53(1), 43-46.

Jobin, P. (2011). Dying for TEPCO? Fukushima's Nuclear Contract Workers 東京電力 のた めに死ぬ? 福島の原発請負労働者. The Asia-Pacific Journall Japan Focus Volume, 9(18).

Johnstone, R., Mayhew, C., \& Quinlan, M. (2000). Outsourcing Risk - The Regulation of Occupational Health and Safety Where Subcontractors are Employed. Comparative Labor Law and Policy Journal, 22, 351.

Johnstone, R., \& Quinlan, M. (2006). The OHS regulatory challenges posed by agency workers: evidence from Australia. Employee Relations, 28(3), 273-289. https://doi.org/10.1108/01425450610661243

Kenny, B., \& Bezuidenhout, A. (1999). Contracting, complexity and control: An overview of the changing nature of subcontracting in the South African mining industry. JOURNAL-SOUTH AFRICAN INSTITUTE OF MINING AND METALLURGY, 99(4), $185-192$.

Kirksey, G. B. (1992). Minimum Decencies-A Proposed Resolution of the Pay-WhenPaid/Pay-If-Paid Dichtomy. Construction Lawyer, 12, 1-47.

Lamare, J. R., Lamm, F., McDonnell, N., \& White, H. (2015). Independent, dependent, and employee: Contractors and New Zealand's Pike River Coal Mine disaster. Journal of Industrial Relations, 57(1), 72-93. https://doi.org/10.1177/0022185614560596

Leach, B. (1993). "Flexible" work, precarious future: some lessons from the Canadian clothing industry*. Canadian Review of Sociology/Revue Canadienne de Sociologie, 30(1), 64-82. https://doi.org/10.1111/j.1755-618X.1993.tb00935.x

Lewchuk, W., Clarke, M., \& Wolff, A. de. (2008). Working without commitments: precarious employment and health. Work, Employment \& Society, 22(3), 387-406. https://doi.org/10.1177/0950017008093477

Lingard, H. C., Cooke, T., \& Blismas, N. (2010). Safety climate in conditions of construction subcontracting: a multi-level analysis. Construction Management and Economics, 28(8), 813-825. https://doi.org/10.1080/01446190903480035

Lingard, H., \& Holmes, N. (2001). Understandings of occupational health and safety risk control in small business construction firms: barriers to implementing technological 
controls. Construction Management and Economics, 19(2), 217-226. https://doi.org/10.1080/01446190010002570

Loosemore, M., \& Andonakis, N. (2007). Barriers to implementing OHS reforms - The experiences of small subcontractors in the Australian Construction Industry. International Journal of Project Management, 25(6), 579-588. https://doi.org/10.1016/j.ijproman.2007.01.015

Loosemore, Martin, \& Waters, T. (2004). Gender Differences in Occupational Stress Among Professionals in the Construction Industry. Journal of Management in Engineering, 20(3), 126-132. https://doi.org/10.1061/(ASCE)0742-597X(2004)20:3(126)

Love, P. E. D., Edwards, D. J., \& Irani, Z. (2010). Work Stress, Support, and Mental Health in Construction. Journal of Construction Engineering and Management, 136(6), 650658. https://doi.org/10.1061/(ASCE)CO.1943-7862.0000165

Macfie, R. (2013). Tragedy at Pike River Mine. Awa Press. Retrieved from http://www.goodreads.com/work/best_book/27072448-tragedy-at-pike-river-minehow-and-why-29-men-died

Mayhew, C., Quintan, M., \& Ferris, R. (1997). The effects of subcontracting/ outsourcing on occupational health and safety: Survey evidence from four australian industries. Safety Science, 25(1-3), 163-178. https://doi.org/10.1016/S0925-7535(97)00014-3

Min, K. B., Park, S. G., Song, J. S., Yi, K. H., Jang, T. W., \& Min, J. Y. (2013). Subcontractors and increased risk for work-related diseases and absenteeism. American Journal of Industrial Medicine, 56(11), 1296-1306. https://doi.org/10.1002/ajim.22219

Mohan M. Kumaraswamy, \& Jason D. Matthews. (2000). Improved Subcontractor Selection Employing Partnering Principles. Journal of Management in Engineering, 16(3). https://doi.org/10.1061/(ASCE)0742-597X(2000)16:3(47)

Moore, J. (1997). The Other Japan: Conflict, Compromise, and Resistance Since 1945. M.E. Sharpe.

Morantz, A. D. (2013). Coal Mine Safety: Do Unions Make a Difference? Industrial \& Labor Relations Review, 66(1), 88-116. https://doi.org/10.1177/001979391306600104

Muzaffar, S., Cummings, K., Hobbs, G., Allison, P., \& Kreiss, K. (2013). Factors Associated With Fatal Mining Injuries Among Contractors and Operators: Journal of Occupational and Environmental Medicine, 55(11), 1337-1344. https://doi.org/10.1097/JOM.0b013e3182a2a5a2

Ng, S. T., Cheng, K. P., \& Skitmore, R. M. (2005). A framework for evaluating the safety performance of construction contractors. Building and Environment, 40(10), 13471355. https://doi.org/10.1016/j.buildenv.2004.11.025

Ng, S. T., Tang, Z., \& Palaneeswaran, E. (2009). Factors contributing to the success of equipment-intensive subcontractors in construction. International Journal of Project Management, 27(7), 736-744. https://doi.org/10.1016/j.ijproman.2008.09.006

Owen, C., Healey, A. N., \& Benn, J. (2013). Widening the scope of human factors safety assessment for decommissioning. Cognition, Technology \& Work, 15(1), 59-66. https://doi.org/10.1007/s10111-012-0219-6 
Padavic, I. (2005). Laboring under Uncertainty: Identity Renegotiation among Contingent Workers. Symbolic Interaction, 28(1), 111-134. https://doi.org/10.1525/si.2005.28.1.111

Papadopoulos, G., Georgiadou, P., Papazoglou, C., \& Michaliou, K. (2010). Occupational and public health and safety in a changing work environment: An integrated approach for risk assessment and prevention. Safety Science, 48(8), 943-949. https://doi.org/10.1016/j.ssci.2009.11.002

Quinlan, M. (2014). Ten Pathways to Death and Disaster: Learning from Fatal Incidents in Mines and Other High Hazard Workplaces. Federation Press.

Quinlan, M., \& Bohle, P. (2004). Contingent work and occupational safety. In J. Barling \& M. R. Frone (Eds.), The psychology of workplace safety (pp. 81-105). Washington, DC, US: American Psychological Association.

Rebitzer, J. B. (1995). Job Safety and Contract Workers in the Petrochemical Industry. Industrial Relations: A Journal of Economy and Society, 34(1), 40-57. https://doi.org/10.1111/j.1468-232X.1995.tb00359.x

Rodgers, J., \& Rodgers, J. (1989). Precarious jobs in labour market regulation: the growth of atypical employment in Western Europe. International Institute for labour studies Geneva.

Roquelaure, Y., LeManach, A. P., Ha, C., Poisnel, C., Bodin, J., Descatha, A., \& Imbernon, E. (2012). Working in temporary employment and exposure to musculoskeletal constraints. Occupational Medicine, 62(7), 514-518. https://doi.org/10.1093/occmed/kqs004

Roughton, J. E. (1995). Contractor safety. Professional Safety, 40(1), 31.

Rousseau, D. M., \& Libuser, C. (1997). Contingent workers in high risk environments. California Management Review, 39(2), 103-123.

Sætren, G. B., \& Laumann, K. (2015). Effects of trust in high-risk organizations during technological changes. Cognition, Technology \& Work, 17(1), 131-144. https://doi.org/10.1007/s10111-014-0313-z

Safe Work Australia. (2013). Mining fact sheet. Retrieved from http://www.safeworkaustralia.gov.au/sites/swa/about/publications/pages/fs2010minin ginformationsheet

Safe Work Australia. (2015). Construction Industry Profile. Retrieved from http://www.safeworkaustralia.gov.au/sites/swa/about/publications/pages/constructionindustry-profile

Sawacha, E., Naoum, S., \& Fong, D. (1999). Factors affecting safety performance on construction sites. International Journal of Project Management, 17(5), 309-315. https://doi.org/10.1016/S0263-7863(98)00042-8

Simon, J. M., \& Piquard, P. (1991). Contractor Safety Performance Significantly Improves. Society of Petroleum Engineers. https://doi.org/10.2118/23253-MS

Suruda, A., Whitaker, B., Bloswick, D., Philips, P., \& Sesek, R. (2002). Impact of the OSHA Trench and Excavation Standard on Fatal Injury in the Construction Industry. Journal of Occupational and Environmental Medicine, 44(10). Retrieved from 
http://journals.1ww.com/joem/Fulltext/2002/10000/Impact_of_the_OSHA_Trench_an d_Excavation_Standard.7.aspx

Thébaud-Mony, A. (2011). Work, Health and Environment Series : Nuclear Servitude: Subcontracting and Health in the French Civil Nuclear Industry. Amityville, US: Baywood Publishing Company, Inc. Retrieved from http://site.ebrary.com/lib/alltitles/docDetail.action?docID=10607826

Trajkovski, S., \& Loosemore, M. (2006). Safety implications of low-English proficiency among migrant construction site operatives. International Journal of Project Management, 24(5), 446-452. https://doi.org/10.1016/j.ijproman.2005.11.004

Uher, T. E. (1991). Risks in subcontracting: Subcontract conditions. Construction Management and Economics, 9(6), 495-508. https://doi.org/10.1080/01446199100000038

Uher, T. E., \& Ritchie, J. (1998). Promoting the health of construction workers. Engineering, Construction and Architectural Management, 5(3), 304-311. https://doi.org/10.1108/eb021084

Underhill, E., \& Quinlan, M. (2011). How Precarious Employment Affects Health and Safety at Work: The Case of Temporary Agency Workers. Relations Industrielles / Industrial Relations, 66(3), 397-421.

Weil, D. (1992). Building safety: The role of construction unions in the enforcement of OSHA. Journal of Labor Research, 13(1), 121-132. https://doi.org/10.1007/BF02685455

Zohar, D. (1980). Safety climate in industrial organizations: Theoretical and applied implications. Journal of Applied Psychology, 65(1), 96-102. https://doi.org/10.1037/0021-9010.65.1.96

Zohar, D., \& Luria, G. (2003). The use of supervisory practices as leverage to improve safety behavior: A cross-level intervention model. Journal of Safety Research, 34(5), 567577. https://doi.org/10.1016/j.jsr.2003.05.006 